\title{
Physician Office
}

National Cancer Institute

\section{Source}

National Cancer Institute. Physician Office. NCI Thesaurus. Code C16988.

A medical facility where a doctor sees and treats patients. 